\title{
Intézményi környezet és helyi fejlesztések: elköteleződések szabta lehetőségek a telepprogramok megvalósításában
}

\author{
Institutional environment and local development: commitment \\ constrained opportunities in the implementation of \\ settlement programs
}

\author{
KELLER JUDIT, VIRÁG TÜNDE
}

\begin{abstract}
KELLER Judit: tudományos munkatárs, Közgazdaság- és Regionális Tudományi Kutatóközpont, Regionális Kutatások Intézete; 1097 Budapest, Tóth Kálmán u. 4.; keller.judit@krtk.hu; https://orcid.org/0000-0002-9970-4993

VIRÁG Tünde: tudományos fömunkatárs, Közgazdaság- és Regionális Tudományi Kutatóközpont, Regionális Kutatások Intézete; 1097 Budapest, Tóth Kálmán u. 4.; virag.tunde@krtk.hu; https://orcid.org/0000-0003-3799-3328
\end{abstract}

KULCSSZAVAK: térbeli igazságosság; helyi adottságokból kiinduló fejlesztési paradigma; többszintű kormányzás; telepfelszámolás

ABSZTRAKT: A helyi tudásra és adottságokra építő fejlesztési megközelítés (place-based approach) az Európai Unió (EU) kohéziós politikájának több mint egy évtizede egyik meghatározó módszertani megközelítése. Célja a társadalmi kirekesztés és a térbeli-társadalmi egyenlőtlenségek enyhítése egy olyan többszintű kormányzási intézményrendszeren keresztül, amelyben a helyi kapacitásokat és tudásokat a fejlesztéspolitikai mező magasabb területi szintjeiről érkező külső források bevonásával mobilizálják. A helyi adottságokból kiinduló fejlesztési paradigma kritikusai szerint az EU tagállamok közigazgatási és fejlesztéspolitikai intézményrendszere erősen heterogén, ebből adódóan a helyi adottságokból kiinduló fejlesztési beavatkozások az egyes országokban eltérően, különböző eredményességgel működhetnek. Azaz, a helyi adottságokra építő fejlesztések mindig a nemzeti közigazgatási és fejlesztéspolitikai intézményrendszerben értelmezhetők, annak keretei, működési mechanizmusai, a különböző területi szintek közötti együttműködés, az információk és források áramlása, a kompetenciák és kapacitások megosztása meghatározza a helyi fejlesztések mozgásterét a fejlesztési koalíciók kialakításában és működtetésében, a helyi fejlesztési elképzelések és célok megvalósításában. A helyi adottságokra építő fejlesztések vizsgálatakor ezért egyszerre kell figyelembe venni a vertikális - különböző területi szintek intézményei - és a horizontális - helyi szinten kialakuló fejlesztési koalíciók és együttműködések - kapcsolatok, a kompetencia és kapacitás megosztásának jellemzőit, működési mechanizmusait. Tanulmányunkban azt elemezzük, hogy az állam által kialakított fejlesztéspolitika intézményi és szabályozási keretei milyen lehetőségeket kínálnak a helyi szintnek a „telepfelszámolás”, azaz a szegregációs folyamatok megállításának és a lakóhelyi szegregáció oldásának kezelésére. Egy jó gyakorlatként megjelenő esettanulmány alapján bemutatjuk, hogy a fejlesztéspolitika keretei által biztosított lehetőségek mennyiben találkoznak a helyi adottságokkal és tudással, valamint a helyi szinten megfogalmazódó igényekkel, lehetőségekkel és elköteleződéssel, s hogy a fejlesztési elképzelések megvalósításához helyi szinten milyen erőforrásokat lehet és kell mozgósítani.

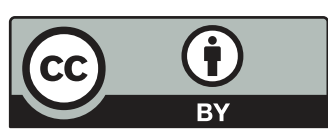


Judit KELLER: research fellow, Institute for Regional Studies, Centre for Economic and Regional Studies; Tóth Kálmán u. 4., H-10977 Budapest, Hungary;keller.judit@krtk.hu; https://orcid.org/ 0000-0002-9970-4993

Tünde VIRÁG: senior research fellow, Institute for Regional Studies, Centre for Economic and Regional Studies; Tóth Kálmán u. 4., H-10977 Budapest, Hungary;virag.tunde@krtk.hu;https:// orcid.org/0000-0003-3799-3328

KEYWORDS: spatial justice; place-based approach; multi-level governance; settlement programs

ABSTRACT: This paper studies the ways place-based interventions embedded in multilevel policy systems can make a positive contribution to spatial justice. Drawing on the idea that place matters, the place-based approach advocates that socio-spatial inequalities can be overcome by the production of place-tailored public goods designed and implemented through integrated and deliberative policy decisions, which guarantee the more equitable distribution of public resources. Within the EU's multilevel governance system, the EU has provided incentives for place-based policies through its cohesion policy for over a decade. In this multi-level system the role of external agents, such as the European Commission and the central state, is to help local actors to mobilize resources 'from below' through an enabling regulative framework.

However, research has found that place-based interventions, in order to generate positive resources for local development, must be based on a 'virtuous relationship' between various scales of government. This relationship is shaped by a governance framework that applies principles of distributed authority, integration of various branches of policies, and partnership between the central state, lower levels of state and non-state actors.

This study analyses local desires for change and capacities in a series of place-based interventions in the disadvantaged neighbourhood of György-telep shaped by the governance framework of domestic policy regimes in which they were embedded. We interrogate the extent to which the Hungarian institutional and regulatory framework meets place-based desires, knowledge and capabilities and the kind of capacities local agents need to mobilize in order to foster integrated housing policies.

Overall, our findings suggest that the state's commitment to principles of spatial justice is a key factor in the efficiency of place-based interventions. State commitment to spatial justice can bring stability to governance structures, and enable the upscaling and long-term success of placebased interventions. State commitment can also ensure a 'virtuous' representation of the public good, i.e. the accommodation of diverse understandings of the concept in policy decisions without favouring any particular representations. Our study demonstrates that in the absence of such commitments and strong local capacities for community action, the state can in fact co-opt placebased initiatives to promote national policy objectives rather than furthering local social cohesion. On the other hand, the low efficiency of place-based interventions is also related to the local state's lack of commitment. The analysis of place-based projects in György-telep indicates that the implementation of settlement programs is often constrained by conflicting local relations and the lack of local commitment to social cohesion goals. The case of place-based interventions in Györgytelep also testifies to the limits of Cohesion Policy-funded place-based initiatives in the EU's multilevel governance system. Our study indicates that the effects of domestic institutional constellations can often be stronger than the catalysing role of place-based development. Placebased interventions have weak capacities for affecting domestic policy systems through spill-overs and social learning. If national policy objectives are based on the systematic reproduction of injustice narrowly targeted place-based projects cannot provide spatial justice for marginalized communities. 


\section{Bevezetés}

A cigánytelepek felszámolásának politikai ígérete mintegy két évtizede időről időre felbukkan a fejlesztéspolitikai célok és stratégiai dokumentumok szintjén. A közbeszédben cigánytelep-felszámolásként megjelenő ígéret a hátrányos helyzetű társadalmi csoportok, ezen belül is kiemelten a romák integrációjának térben is megvalósítandó víziójaként fogant, de a különböző fejlesztéspolitikai megközelítések a politikai változásokkal párhuzamosan az esélyegyenlőségelvü fejlesztéspolitikai céloktól a többségi társadalomhoz való felzárkóztatás elősegítéséig, majd a cigányság aktív részvételén és felelősségén alapuló társadalmi felzárkózás felé mozdultak el.

A fejlesztéspolitikai megközelítések változása tükröződik a 2005 és 2016 között megvalósított modellkísérletek célkitűzéseiben és fejlesztési gyakorlataiban is. ${ }^{1}$ Tanulmányunkban bemutatjuk, hogy az állam által kialakított fejlesztéspolitika intézményi és szabályozási keretei milyen lehetőségeket kínálnak a helyi szintnek a „telepfelszámolás”, azaz a szegregációs folyamatok megállításának és a lakóhelyi szegregáció oldásának kezelésére, ez mennyiben találkozik a helyi adottságokkal és tudással, valamint a helyi szinten megfogalmazódó igényekkel és lehetőségekkel, és ezekhez helyi szinten milyen erőforrásokat lehet és kell mozgósítani. Elemzésünk középpontjába azt a kérdést helyeztük, hogy az állam milyen intézményes kereteket, forrásokat és szabályozókat biztosít a lokális szintnek a térbeli igazságosság megvalósítására a helyi adottságokból kiinduló és a helyi tudásra építő fejlesztéseken keresztül, valamint mekkora mozgásteret ad a lokális szintnek arra, hogy meghatározza saját fejlesztési elképzeléseit.

A helyi tudásra és adottságokra építő fejlesztési megközelítés (place-based approach) az Európai Unió (EU) kohéziós politikájának több mint egy évtizede egyik meghatározó módszertani megközelítése. Célja a társadalmi kirekesztés és a térbeli-társadalmi egyenlőtlenségek enyhítése egy olyan többszintű kormányzási intézményrendszeren keresztül, amelyben a helyi kapacitásokat és tudásokat a fejlesztéspolitikai mező magasabb területi szintjeiről érkező, külső források bevonásával mobilizálják. A szakirodalom a térbeli-társadalmi egyenlőtlenségek állandósuló mintázatait olyan térbeli igazságtalanságoknak (spatial injustice) tekinti, amelyek a társadalom által értéknek tekintett javak elosztásában (distributive justice), illetve az azt irányító eljárásrendekben (procedural justice) nem a méltányosság elve szerint szerveződnek (Soja 2009). Térbeli igazságosság (spatial justice), azaz a javak térbeli elosztásának és közpolitikai intézményi folyamatainak méltányossága, a helyi társadalom széles körü bevonásával, olyan intézményi környezetben valósulhat meg, amely kívülről támogatja a helyi igényekhez igazodó, helyi tudásra épülő kezdeményezéseket (Madanipour, Shucksmith, Talbot 2017).

A helyi adottságokból kiinduló fejlesztési paradigma kritikusai szerint az EU-tagállamok közigazgatási és fejlesztéspolitikai intézményrendszere erősen heterogén, ebből adódóan a helyi adottságokból kiinduló fejlesztési beavatkozá- 
sok az egyes országokban eltérően, különböző eredményességgel működhetnek. A helyi adottságokból kiinduló paradigma nem reflektál a tagállamok közötti tágabb történelmi folyamatok és társadalmi viszonyok sajátosságaira, gyakran figyelmen kívül hagyja a nemzeti állam szabályozó szerepének fontosságát és a belpolitika hatását az intézményrendszerek dinamikájára (Horlings, Roep, Wellbrock 2018; Rodríguez-Pose 2013). Ebből adódóan ignorálja a központi állam bürokratikus, centralizációs és klientalista struktúráinak különböző megjelenési formáit, amelyek ugyanakkor kihatnak a helyi problémák, valamint az állam és a társadalom közti kapcsolatok kezelésére (Surubaru 2016).

A szilárd intézményrendszer elégséges feltételébe vetett hit a „képessé tevő állam" (enabling state) (Gilbert 1989) ideáltipikus jelenlétére épül, amely állam a heterarchikus fejlesztési koalíciók létrehozását részesíti előnyben a járadékszerzésen alapuló, egyes szereplőket monopolhelyzetbe hozó fejlesztési csoportokkal szemben. A heterarchikus koalíció úgy szervezi meg a különböző ágazati és társadalmi beágyazottságú szereplők együttműködését, hogy abban egyik szereplő sem dominálhat mások felett (Bruszt 2002). A politikai és adminisztratív központok túlzott dominanciája, a többszintű kormányzás különböző területi szintjei közötti feszültség és a centralizáció különösen megnehezíti a helyi adottságokon alapuló politikák megvalósítását azokban az országokban, ahol a helyi autonómia csökkenése feszültséget okozott a helyi és a központi állam szintje között (Beer et al. 2020). Azaz, a helyi adottságokra építő fejlesztések mindig a nemzeti közigazgatási és fejlesztéspolitikai intézményrendszerben értelmezhetők, annak keretei, működési mechanizmusai, a különböző területi szintek közötti együttműködés, az információk és források áramlása, a kompetenciák és kapacitások megosztása meghatározza a helyi fejlesztések mozgásterét a fejlesztési koalíciók kialakításában és működtetésében, a helyi fejlesztési elképzelések és célok megvalósításában. A helyi adottságokra építő fejlesztések vizsgálatakor ezért egyszerre kell figyelembe venni a vertikális - különböző területi szintek intézményei - és a horizontális - helyi szinten kialakuló fejlesztési koalíciók és együttműködések - kapcsolatok, a kompetencia és kapacitás megosztásának jellemzőit, múködési mechanizmusait.

E hatalmi viszonyok és kapcsolatok által kialakított müködési mechanizmusok összessége azt is meghatározza, hogy ki és miként szólhat bele a fejlesztések tervezésébe, a fejlesztéspolitika kormányzásába (governance of development). Ez a formális és informális intézményi mechanizmusok összességét jelenti, amely a közösségi fellépések alapjaként szabályozza a különböző típusú, állami és nem állami, helyi és nemzeti szintű, magán- és közszereplők egymáshoz való viszonyát, interakcióit (Stoker 1997; Pierre 2014), a hatalom és a források elosztásának különböző módjait (Pierre 2014). Ez az elemzési keret érzékeny mind a formális hatalom intézményeire, mind a kevésbé intézményesült társadalmi normákra, így lehetővé teszi a különböző típusú szereplők közötti interakciók és a tényleges intézményi gyakorlatok tanulmányozását az állam különböző adminisztratív szint- 
jei és a helyi megvalósítók között. A helyi ágencia (local agency) elemzése a helyi szereplők/megvalósítók stratégiaalkotását, kezdeményezéseit, koalícióinak építését és működtetését vizsgálja, azt, hogy helyi szereplők miként formálják a tereket és az intézményeket a helyi közösségek igényei, ismeretei és eszközei szerint (Pierre 2014; Horlings, Roep, Wellbrock 2018).

A nemzetállami tényezők szerepe a belföldi intézményrendszerek alakításában jelentős mértékben megnőtt a 2004-es EU-csatlakozást követően, míg az EU (a Bizottság) kapacitása a közpolitikai koordinációban és szankcionálásban erősen korlátozottá vált (Barca, McCann, Rodríguez-Pose 2012; Wozniakowski, Schimmelfennig, Matlak 2018). A közpolitikák a Bizottság és a nemzeti kormányok közti tárgyalási folyamatban formálódnak (Barca, McCann, Rodríguez-Pose 2012, 143.), ami jelentős diszkrecionalitást biztosít a tagállamoknak abban, hogy a tárgyalásokat "csonka szerződésekkel” zárják le (McAleavey 1995, idézi Bachtler, Mendez, Oraže 2013). A 2004-ben csatlakozó közép-európai országokban a többszintű kormányzás elveit egy évtizeddel a csatlakozás után is felszínesen és következetlenül alkalmazzák (Dabrowski 2014; Telle, Špaček, Crăciun 2019). Noha a kohéziós politika végrehajtásához technikailag szükséges intézményrendszer felállt és működik ezekben az országokban, a politikai ciklusokon átívelő stratégiai tervezést továbbra is akadályozza a központosított tervezés, a helyi szint gyenge adminisztratív és pénzügyi kapacitása, a klientalizmus és a bizalmatlanság örökségének továbbélése (Dabrowski 2014; Telle, Špaček, Crăciun 2019).

Tanulmányunkban azt állítjuk, hogy ha a nemzeti szintủ közpolitika általános elvei és az intézményrendszer müködése a helyalapú fejlesztés intézményi logikájával és annak céljaival ellentétesek, akkor a helyi fejlesztési beavatkozások a nemzeti kormányok politikai céljainak megfelelően módosulnak. Azaz a helyi adottságokra építő megközelítés intézményi felépítése a helyi fejlesztési beavatkozásokat rendkívül sebezhetővé teszi a politika, különösen a politikai változások szempontjából. Ugyanakkor bizonyos helyzetekben éppen a helyi szint „ellenállása" akadályozza a nemzeti szinten megfogalmazott fejlesztési elképzelések megvalósítását.

Elemzésünk a horizontális és vertikális intézményi keretek és müködési mechanizmusok vizsgálatára fókuszálva először bemutatja, hogy a nemzeti intézményi és szabályozási környezet hogyan befolyásolja a helyi fejlesztések lehetőségeit, a helyi szintnek milyen erőforrásokat lehet és kell mozgósítania a fejlesztés megvalósításának, vagy éppen a nemzeti szinten megfogalmazott fejlesztési elképzelések módosítása érdekében. A tanulmány első részében áttekintjük a telepfelszámolások különböző fejlesztési modelljeit, a politikai és intézményi környezetet és fejlesztéspolitikai elképzelések változását, azaz azt a keretet, amit a nemzeti kormányok az uniós csatlakozást követően, elsősorban a 2007-2014-es fejlesztési időszakban a helyi szintnek eszközként a telepek felszámolására kialakítottak.

Ezek után egy, a RELOCAL kutatás keretében a pécsi a György-telepen készült esettanulmány (Jelinek, Virág 2019) példáján keresztül mutatjuk be, hogy a 
város egyik szegénytelepének felszámolására irányuló helyi szintű fejlesztési elképzelések és a szereplők mozgástere miként alakult a változó intézményi keretek között. Az esettanulmány a hazai fejlesztéspolitika egyik jó gyakorlataként jelenik meg, ami elsősorban a „terepen” dolgozó fejlesztők és szociális munkások elkötelezett szakmai munkájának köszönhető.

A kétezres évek közepén a pécsi György-telep a város egyik nagyon leromlott szegregátuma volt, az egykori bányatelepen többségében komfort nélküli bérlakásokban éltek szegény roma és nem roma családok. A telepen koncentrálódó lakhatási és szociális gondok évtizedeken át csak halmozódtak, és egy idő után a város vezetése számára megoldhatatlan problémaként jelentkeztek. György-telepen a Máltai Szeretetszolgálat (a továbbiakban Málta) munkatársai 2007-ben kezdték el a folyamatos jelenléten alapuló szociális munkát, majd az EU fejlesztési kiírásainak megjelenésével több lakhatási és a társadalmi felzárkózást célzó fejlesztési projektet valósítottak meg. Az esettanulmányra támaszkodva bemutatjuk, hogy a helyi - politikai, szakmai - szereplők elkötelezettsége, forrásallokációs lehetősége és képessége hogyan írják felül, vagy éppen korrigálják a centralizált, hierarchikus, projektcentrikus, felülről vezérelt fejlesztési kormányzásból (Somlyódyné Pfeil 2020) fakadó ellentmondásokat. Mivel a fejlesztéspolitika által kitüzött és a helyi szinten megfogalmazott célok csak részben feleltek meg egymásnak, a helyi megvalósítás során a mindennapi és intézményes gyakorlatok gyakran informalizálódtak. A helyi fejlesztések ugyanakkor nem ágyazódtak be a helyi közpolitika intézményrendszerébe olyan mértékben, hogy azon keresztül strukturális változások indulhassanak el a társadalmi és térbeli igazságosság megteremtése érdekében.

\section{A cigánytelepek felszámolásának politikai ígérete és fejlesztéspolitikai kísérletei}

A szocializmusban lezajlott telepfelszámolási akciósorozat átrendezte és a mai napig meghatározza a roma családok térbeli elhelyezkedését egyes településeken belül. A telepfelszámolási program 1965-ben indult, ebben az évben 237, majd 1966-1970 között négy és félezer, 1971 és 1980 között további 18 ezer lakás épült vagy került megvásárlásra a telepről elköltözők számára nyújtott kedvezményes kölcsönre alapozott konstrukciónak köszönhetően (Kozákné 2001, 100-104.). A telepfelszámolás során a telepek egy része - ha jobb lakhatási körülmények között is - újratermelődött (Berey 1990), és a térbeli kirekesztés új formái jelentek meg (Ladányi, Szelényi 2004; Virág 2006). Amikor 1993-ban Kemény István és munkatársai megismételték az 1971-es reprezentatív roma felmérést, azt találták, hogy a hetvenes évekhez képest a telepen élő cigány családok aránya jelentősen visszaszorult, de a cigány családok fele továbbra is olyan lakókörnyezetben élt, ahol kizárólag vagy többségében romákat találhatunk. Ez az arány a 2003-as meg- 
ismételt adatfelvételben kétharmadra növekedett (Janky, Kemény 2004). Egy 2010-ben készült telepösszeírás szerint ,az ország területén 823 településen és 10 fövárosi kerületben összesen 1633 szegény- és cigánytelep, településszövetbe ágyazódott szegregátum található, a telepeken élők számát mintegy 300 ezerre becsülik" (Domokos, Herczeg 2010). A különböző fejlesztéspolitikai törekvések ellenére a szociológiai és antropológiai kutatások rendre a térbeli egyenlőtlenségek és a kirekesztés erősödéséről, a térbeli és társadalmi marginalizáció újabb formáiról, a lakhatás prekarizációjáról számolnak be (Ladányi 2012; Teller 2011).

A 2002-es kormányváltást követően, az EU csatlakozási folyamat prioritásaival összhangban került előtérbe a roma integráció problémája. Nem csak a kormányprogramba kerültek be ,a cigányság társadalmi és politikai integrációjával összefüggő feladatok", a kérdés a Miniszterelnöki Hivatalon belül megalakuló Romaügyi Hivatallal politikai szintre emelkedett (Lengyel 2006). Az oktatási integráció mellett az egyik leghangsúlyosabb, megoldandó feladat a telepfelszámolás lett, amelynek tervezése során 2002-2003-ban 6-700 telep felszámolását ígérték tízmilliárdos, többségében EBRD-hitelből finanszírozott forrásból. Teleki László romaügyi államtitkár ígérete szerint 2006-ig a telepek fele el fog tűnni, de legalább elkezdik felszámolni őket (Varró 2008). Bár a 2004-es, a „romák társadalmi integrációját" elősegítő kormányprogram ${ }^{2}$ még kiemelt helyen kezelte a telepfelszámolás ügyét, a hitelfelvétel meghiúsulásával, és azzal, hogy a térbeli és társadalmi probléma súlyossága mind nyilvánvalóbbá vált, a kormányzati struktúrában az ügy politikai képviselete is meggyengült, ,a kormányzati romapolitikát látványos, de a romák tömegeit nem érintő kérdések határozták meg" (Kállai 2006, 197.). ${ }^{3}$ Az EBRD-hitel meghiúsulásával a csak hazai forrásokra támaszkodó telepfelszámolási program modellprogrammá zsugorodott, ugyanakkor legfontosabb fejlesztési célként mindvégig megtartotta a mobilizációt a telepekről mint a lakhatási integráció legfontosabb eszközét, illetve lakhatási és szociális integráció együttes, komplex módon való megközelítését (Petrovácz, Somogyi, Teller 2010).

A köztudatba telepprogramként bevonuló, a „Roma telepeken élők lakhatási és szociális integrációs modell program" címen futó programot végül 680 milliós forintos hazai forrásból kezdték el megvalósítani, azzal a céllal, hogy négy-hat helyszínen modellezzék a telepfelszámolás lehetséges koncepcióit. ${ }^{4} \mathrm{~A}$ szakmai és politikai egyeztetések eredményeképpen végül kilenc település kapott meghívást a pályázatba, s ennek következményeként egy-egy településen jelentősen csökkent a megvalósításra szánt összeg is. Ugyanakkor fontos kiemelnünk, hogy eleve csak azokon a településeken történt beavatkozás, ahol a településvezetés problémaként érzékelte a romák lakhatási helyzetét, és ezért hajlandó is volt tenni valamit. Azaz, a cigánytelepek felszámolása, a lakhatási integráció megteremtése nem a központi állam felelősségeként, hanem a lokalitás viszonyaitól, szereplőitől függő lehetőségként jelent meg (Lengyel 2006). Hasonlóképpen, a helyi diskurzusok és hatalmi viszonyok határozták meg azt is, hogy egy-egy településen mit tekintettek „cigánytelepnek”. Összességében, a nemzeti kormány „olvadozó” (Kállai 
2006) elkötelezettsége a romák, ezen belül a cigánytelepen élők lakhatási integrációja iránt együtt járt a helyi szint szelektív elkötelezettségével.

A (komplex) telepprogramokat 2005-2009 között a Szociális és Munkaügyi Minisztérium (SZMM) és az Országos Foglalkoztatási Alap (OFA) közösen finanszírozta, a két szervezet azonban külön döntött a támogatásokról. Az eredeti elképzelés szerint a program komplex módon, a lakhatási, foglalkoztatási és szociális problémákat együtt kezelte volna, de ez a szemlélet a kettős irányítás miatt a kezdetektől nehezen érvényesült. Voltak projektek, amelyeket csak az egyik fél támogatott, így vagy a program foglalkoztatási lába hiányzott, vagy a foglalkoztatási programból kellett lecsípni valamennyit a lakhatási programra. A program egyik legfontosabb eleme az SZMM koordinálásával zajló mentorprogram volt. A mentorok rendszeres tereplátogatása volt hivatott biztosítani a szakmaiságot és a program követését, de mindezeken túl a mentorok mediálták a helyi konfliktusokat, segítséget nyújtottak a tervezésben és lebonyolításban, és rendszeresen közvetítették tapasztalataikat a minisztérium felé. Így az évről évre kiírt pályázatok a helyi tapasztalatok és tudás becsatornázásával folyamatosan változtak, ahogy a mentori tevékenység is módosult, finomodott (Petrovácz, Somogyi, Teller 2010). Ez az iteratív, a helyi tudást és tapasztalatokat becsatornázó, a különböző szereplők érdekeit közvetítő tervezési módszer segítette a modellprogram végleges formálódást. A modellprogramban és annak folytatásaként 2005 és 2010 között az ország 47 településén összesen 54 lokális beavatkozás történt (Petrovácz, Somogyi, Teller 2010).

A beavatkozások nem szándékolt következményeként ugyanakkor a telepek több helyen is újratermelődtek. Azzal, hogy a telepről csak az „arra érdemes” családokat költöztették integrált környezetbe, a telep egészét nem szüntették meg. A megüresedő házakba rögtön lettek új beköltözők, a falubeli lakások megvásárlásával pedig a nem romák elköltözését támogatták, azaz a hetvenes években egyszer már lezajlott térbeli folyamatok ismétlődtek meg. A roma családok beköltözése a faluba folyamatos konfliktusokat okozott, a helybeliek gyakran megakadályozták, hogy a település bizonyos részein lakásokat vásároljanak, de az is előfordult, hogy a roma családokat igyekeztek más településre költöztetni (Virág 2008; Durst 2010). Azaz a lakhatási és társadalmi integrációt célzó beavatkozás nem illeszkedett a társadalompolitika intézményrendszeréhez (Farkas 2018), a munkaerőpiaci feltételekhez, és gyakran ellentétes volt a helyi fejlesztési elképzelésekkel és szándékokkal, így a felszínen beavatkozó, elszigetelt lokális pályázati projektek során csak „gettócsinosítás” történt (Révész, Zolnay 2009, 33.).

A telepfelszámolási modellprogrammal párhuzamosan, az uniós források megjelenésével előtérbe került a városrehabilitációs fejlesztések jelentősége, amelyekben nyugat-európai tapasztalatok hatására a fizikai beavatkozások mellett egyre hangsúlyosabbá vált a társadalmi problémák kezelése, a leromlott területek rehabilitációján keresztül a marginalizált társadalmi csoportok integrációja. E logika mentén a 2007-2014-es uniós programozási időszakban megkülönböztet- 
ték a funkcióbővítő és a szociális városrehabilitációs beavatkozásokat. Míg a cigánytelepek felszámolását célzó modellprogram a Szociális Minisztérium alá tartozott, addig a városfejlesztési programokat a Nemzetgazdasági Minisztérium (NGM) koordinálta a Regionális Operatív Programokon (ROP) belül, ami egészen más szemlélettel közelítette meg a problémát. ${ }^{5} \mathrm{~A}$ fejlesztési források elnyeréséért minden pályázó városnak Integrált Városfejlesztési Stratégiát (IVS), ezen belül Antiszegregációs Tervet (ASZT) kellett készítenie egy meghatározott módszertan és tartalom szerint. ${ }^{6}$ Ahhoz, hogy a város hozzáférjen a fejlesztési forrásokhoz, legalább a tervezés szintjén foglalkoznia kellett a közigazgatási határain belül elhelyezkedő szegregált településrészekkel, azok fejlesztésével. Ennek legfontosabb eleme a KSH 2001-es népszámlálási adatai alapján elkészített szegregációs térkép volt, amely tartalmazta a településen belül azokat a területeket, ahol az aktív korú lakosok legalább 50\%-a nem rendelkezik rendszeres munkajövedelemmel, illetve legmagasabb iskolai végzettsége nem haladja meg a nyolc osztályt. A társadalmi helyzet szerint lehatárolt szegregált területek nem minden esetben estek egybe a helyi mindennapi és intézményes gyakorlatok alapján cigánytelepként azonosított területekkel, ami önmagában is formálta a településvezetés fejlesztéspolitikai elképzeléseit (Váradi, Virág 2015).

Az ASZT kitüzött célja az volt, hogy a városok olyan fejlesztési és ágazati intézkedéseket fogalmazzanak meg, amelyek megállítják a szegregációs folyamatokat és oldják a már kialakult szegregációt. Az ASZT módszertani alapját a Városfejlesztési Kézikönyv adta, emellett az SZMM Roma Integrációs Főosztálya felállított egy antiszegregációs szakértői hálózatot, melynek tagjai mentorálták az ASZT elkészítését, és ellenjegyzésük szükséges feltétele volt az ASZT-nek. Ugyanakkor a városok többsége már az ASZT elkészítését, majd a roma mentorokkal való együttmüködést nem segítségként, hanem kényszerként, a kompetenciájukba való beavatkozásként élte meg, és az országos politikában is meghatározó helyi vezetők jelentős része erős lobbitevékenységet folytatott az ASZT legitimációjának gyengítésére. Azaz a kormányzat komolyabb egyeztetési folyamat nélkül bevezetett esélyegyenlőség elvü fejlesztési politikája helyi szinten erős ellenállásba ütközött, ami kormányzati szintre visszacsatolva gyengítette a kormányzati elköteleződést. Így a továbbiakban, bár történtek rá gyenge kísérletek, az ASZT mint esélyegyenlőség elvű fejlesztéspolitikai eszköz teljes körű legitimációt sosem nyert, a kapcsolódó jogszabályok nem biztosították, hogy a konkrét fejlesztési projektek kialakításánál érvényesíteni kelljen az ASZT intézkedéseit. A 2010-es kormányváltást követően, a kormányzati intézkedések hatására az ASZT intézménye fokozatosan vesztett erejéből: a kapcsolódó antiszegregációs szakértői rendszert visszahívták, és nem alakítottak ki helyette másikat, az ASZT egyre inkább a tervezés formális elemévé vált (Somogyi 2013).

Összegezve azt mondhatjuk, hogy 2002 után a nemzeti kormányok részéről bár egyre gyengülő határozottsággal - megfogalmazódott az elköteleződés a cigánytelepek felszámolására, a lakhatási integráció megteremtésére. A két külön- 
böző minisztériumnál (SZMM, NGM) eltérően jelent meg a helyi szint elköteleződése és kötelezettségei iránti igény, ugyanakkor - még ha gyakran informálisan, vagy politikai nyomásgyakorlás formájában - a helyi szintnek mindkét programban volt lehetősége arra, hogy becsatornázza tapasztalatait, véleményét a fejlesztési folyamatba, és azt befolyásolja. Az SZMM-nél megjelenő telepfelszámolási modellprogramot a helyi vezetők szelektív problémaérzékelése és elkötelezettsége, illetve a megkettőzött irányítás (SZMM-OFA) gyengítette. Az NGM által koordinált városrehabilitációs beavatkozások tervezése során pedig, bár a város részeként kellett kezelni a szegregált területeket, a fejlesztések megvalósításakor ezt - a helyi szint ellenállásának eredményeképpen - már nem kérték számon.

\section{Centralizáció és paradigmaváltás}

A hazai finanszírozású telepprogramok politikai ígérete az volt, hogy annak tapasztalatai beépülnek a 2007-2014 EU-s fejlesztési időszak tervezésébe, az uniós források bősége pedig majd lehetőséget teremt a telepprogramok kiterjesztésére. A Nemzeti Fejlesztési Ügynökség (NFÜ) kezdeményezésére 2009-ben megkezdték a program EU-s finanszírozású tervezését, számos támogatható tevékenységet és a probléma általános megközelítésének módját és céljait átemelve a modellprogramból. Az első felhívás 2010 tavaszán jelent meg, amit visszavontak, majd a végleges felhívást 2012 tavaszán tették közzé „Komplex telep-program” címen.7 A felhívásban már tükröződött a 2010-es kormányváltással élesebbé váló közpolitikai fordulat, ami a kormányzás szintjén az erőteljes centralizációt, a közpolitika szintjén pedig a társadalmi integráció helyett a felzárkóztatás, a későbbiekben a felzárkózás szemléletét jelentette.

Az önkormányzatok döntő többsége saját források híján korábban is kényszerủen arra pályázott, amire támogatást tudott szerezni (Mezei 2019), és esetlegesen, a felülről meghatározott fejlesztési célokat igazította, többnyire informálisan, a helyi igényekhez. A decentralizált, hazai fejlesztési források eltünése, az EU-források kizárólagossá válása és az állami kontroll erősödése a fejlesztési források és célok kijelölése felett tovább szűkítette az önkormányzatok lehetőségeit. A centralizációs folyamat a 2010 után bekövetkező átfogó közpolitikai és közigazgatási átalakításokkal lépett szintet. A korábbi “jó kormányzás” szervezőelv helyett a "jó állam" paradigmája nyert teret, amely megváltoztatta az "állam szervezet- és eszközrendszerét, előnyben részesítve a hierarchiát, a bürokratikus eszközöket, a decentralizációval és horizontalitással szemben" (Pálné Kovács 2014, 3.). Az önkormányzatok köznevelési, oktatási, egészségügyi, államigazgatási funkcióinak jelentős részét elvonták és központosították (Hegedüs, Péteri 2015), így az önkormányzatok mozgásterét a helyi szolgáltatások biztosításában jelentősen szükítették (Tagai 2021). Ezzel az önkormányzatok olyan intézményi környezetbe kerültek, amelyben egyszerre volt jelen a központi állami centralizá- 
ció és az állam szelektív kivonulása a hátrányos helyzetű népességet érintő intézményi terekből (Kovai, Szőke 2021). E két, látszólag ellentmondásos folyamatot a közigazgatásban és a közpolitikai intézményrendszerben egyaránt megnövekedett bürokratikus ellenőrzési mechanizmusok kötötték össze. Így egy intézményi logikában együtt járhatott a központosított túlszabályozás és az állami kivonulás (Keller 2020).

Az önkormányzati rendszer centralizációjával párhuzamosan zajlott az EU-s fejlesztési források menedzseléséért felelős hazai intézményrendszer átalakítása. Az EU-s programozási időszak végére, 2014-ben hivatalosan is megszűnt a NFÜ, amely addig az EU-s fejlesztések programozásában, bonyolításában és monitorozásában kiemelt szerepet játszott, és megszűntek a regionális fejlesztési ügynökségek is, melyek a fejlesztési projektek területspecifikus megvalósítását voltak hivatottak elősegíteni. Ezek helyét egyrészt a minisztériumok alá rendelt Irányító Hatóságok (IH), másrészt a politikailag is erősebben ellenőrzött új tervezőintézetek vették át (Jelinek 2019, 2020). Az NFÜ felszámolásával és az IH-k minisztériumok alá rendelésével megszűnt az önálló fejlesztéspolitika, és szigorú ágazati szemlélet vált uralkodóvá, tovább fragmentálva az amúgy is töredezett érdekek mentén működő fejlesztéspolitikai intézményrendszert (Keller 2020). A centralizáció és az állami politikai kontroll erősödése, a helyi szint döntési lehetőségeinek kiüresedése megerősítette az államtól függővé tett településfejlődést (Somlyódyné Pfeil 2020). ${ }^{8}$

Az EU-s fejlesztési projektek kiírásán és a források újraelosztásán keresztül egyre növekvő mértékben lett az állam kizárólagos joga a fejlesztési célok meghatározása, ugyanakkor a központi állam a program megvalósítását - hasonlóan az eddigi gyakorlatokhoz - a helyi szint szelektív elköteleződésére bízta, azaz, hogy pályáznak-e az adott forrásra vagy sem. A Komplex telepprogram fejlesztési céljait a központi kormányzat határozta meg, és a megvalósításhoz kötelező partnereket jelölt ki: a képzésekért, a beavatkozási terv elkészítéséért az EMMI háttérintézményeként működő országos lefedettségű Türr István Képző és Kutató Intézet (TKKI) lett felelős, amely jellemzően országszerte nagyon hasonló képzéseket ajánlott a különböző hátrányos helyzetű társadalmi csoportok felzárkóztatását célzó fejlesztési programoknak. ${ }^{9}$ Mivel a városokban csak olyan akcióterülettel lehetett pályázni, ami az ASZT-ben társadalmi helyzet alapján kialakított, a KSH mutatói alapján lehatárolt szegregátumként jelent meg, az Országos Roma Önkormányzat (ORÖ) kötelező bevonása hivatalosan azt a célt szolgálta, hogy a fejlesztési projekt biztosan elérje a helyi roma közösségeket. Az ORÖ bevonása és szerepe a gyakorlatban inkább szimbolikus volt, és a kormányzat romapolitika iránti elköteleződését volt hivatott bizonyítani. Ugyanakkor a társadalmi mutatók alapján lehatárolt területi fókuszú fejlesztés és a cigánytelepek felszámolásának kormányzati kettős kommunikációja a megvalósítás során, helyi szinten feszültségeket okozott: a helyi roma szervezetek roma projektként, míg más megvalósítók egy területi alapú beavatkozásként értelmezhették. 
A pályázati felhívásban a fejlesztés központi eleme az aktív, állandó (settlement típusú) szociális munka lett, ${ }^{10}$ aminek mintáját a Málta Jelenlét programja szolgáltatta. Már az SZMM által koordinált telepfelszámolási programban is hangsúlyos elem volt a telepen élő családokkal való folyamatos szociális munka, de akkor annak még kifejezetten az volt a célja, hogy segítse a felkészítést az integrált környezetbe költözésre. Ezzel szemben a Jelenlét program alapvetően a telepen belül végzett közösségi szociális munka. A TÁMOP pályázat kiírásakor a Jelenlét programnak nem volt egységes módszertana, az alapvetően a Málta által kezdeményezett különböző settlement típusú szociális munka addigi tapasztalatait jelentette (Csonkáné Utasi, Dusa, Fehér 2011; Kiss 2011), azaz „a program módszertana egy, az elmúlt másfél évtized alatt közvetlenül a telepi szociális munka során kialakult technikákból nőtt ki" (Katona et al. 2020,12.). Bár a pályázati felhívás egy pontosan definiált, kötelező intézményi keretet jelölt ki a megvalósításra (Csillagház-Csillagpont), azt a helyi megvalósítókra bízta, hogy ott milyen tartalmú szociális munka valósuljon meg. A szociális munka módszertani támogatásának hiánya miatt a helyi megvalósítás a helyi hatalmi és társadalmi viszonyok lenyomataként jelent meg, és tükrözte a településpolitikát formáló vezetők, a településen élő többségi lakosság szegényekhez, etnikai csoportokhoz való, helyi gyakorlatokban, diskurzusokban és politikákban megjelenő viszonyát. Mindez meghatározta azt is, hogy a lokális intézmények milyen mértékben és módon érhetők el a különböző szegregált terekben élő szegény, roma népesség számára (Váradi, Virág 2015), illetve hogy a program során kötelezően kialakítandó intézmények (Csillagház-Csillagpont) milyen funkciót töltenek be, hogyan kapcsolódnak a helyi szociális és oktatási intézményekhez, programokhoz és fejlesztési elképzelésekhez (Virág 2020).

A módszertani és szakmai támogatás nélkül, kötelezően kialakítandó intézmények megfelelő keretet adtak a kormányzati szinten megjelenő és onnan lecsorgó felzárkóztatási paradigma helyi megvalósításának. Ahogyan erre egy, a Jelenlét programokat összehasonlító tanulmány rámutatott: „A legnagyobb közös nevező az egyes terepi programok céljai között, hogy úgy váljanak élhetőbbé a telepek, hogy egy-egy telep életét hosszú távon elköteleződve, azaz nem azonnali változást várva kísérje-segítse a terepen zajló szociális munka. Gyakorlatilag a napi tevékenységek összerendeződése az, amely egy adott telep esetében kiadja a Jelenlét program tartalmát" (Katona et al. 2020,12.). Azaz a programok a telepeken élők társadalmi és térbeli integrációja helyett elsősorban a telepen belüli viszonyok konszolidációjára fókuszálnak, és hangsúlyossá teszik az egyéni felelősséget, ami pontosan illeszkedik a 2010 után megjelenő felzárkózási paradigmába.

A felzárkóztatás majd felzárkózás kifejezések használata 2010 után jelent meg újra a hazai közpolitikák, ezeken belül is elsősorban az oktatáspolitika szótárában, ${ }^{11}$ és erősen kapcsolódott a Balog Zoltán vezette, hasonló nevü államtitkársághoz. A társadalmi felzárkózás fogalmát az Egyenlő Bánásmódról és Esélyegyenlőség előmozdításáról szóló CXXV/2003 törvény tartalmi változtatására irányuló ne- 
gyedik Alaptörvény-módosítás (2013. március 25.) emelte törvényi szintre (Mike 2013). Bár a két fogalom lényegileg különbözött egymástól, a felzárkóztatás és felzárkózás fogalmakat a későbbiekben sem használták következetesen a társadalmi hátrányok felszámolásával összefüggésben. A két fogalom közötti különbség abban áll, hogy az állam milyen mértékben tekinti saját, illetve az érintett csoportok vagy egyének felelősségének, feladatának a társadalmi egyenlőség elősegítését (Mike 2013). Az oktatási gyakorlatban megjelenő "szeretetteljes szegregáció" (Kegye 2015) azt fejezi ki, hogy a kormányzat bizonyos esetekben elismerhetőnek tartja az elkülönítést. Ehhez hasonlóan a telepfelszámolás során a szociális munka elsődleges célja az lett, hogy a telepi viszonyokat konszolidálja, a telepen élő családokat - meghatározatlan ideig - felkészítse a telepről való elköltözésre. Ezzel az állam megkérdőjelezi az esélyegyenlőségi elvű hozzáállást, és a felzárkóztatást elsősorban paternalista, asszimilációs elvárásokat közvetítő megközelítésként használja.

A Komplex telepprogram telepfelszámolásként értelmezett kormányzati és helyi kommunikációját nehezítette, hogy a 2012-ben megjelenő pályázati felhívásban nem voltak lakhatási elemek. Másfél évvel később jelent meg az a pályázati felhívás, ${ }^{12}$ amelyben már a lakhatási elemeket is meg lehetett valósítani ERFA-forrásból, ami mind a telepen belüli házak felújítását, mind a telepről való mobilizációt támogatta. A telepfelszámolások és ezzel a lakhatási integráció megteremtésének legerősebb strukturális akadálya a közösségi tulajdonban levő lakások nagyon alacsony aránya (Misetics 2013), amely eleve meghatározta, hogy csak azokon a jellemzően városi telepeken indult el infrastrukturális beruházás, ahol a helyi önkormányzatnak jelentős ingatlantulajdona volt. Így a Komplex telepprogram településeinek csak töredéke jutott ehhez a forráshoz, és a megvalósítást az is nehezítette, hogy mire a lakhatási elemek megvalósulhattak volna, a szociális munkán alapuló program már több helyen befejeződött, saját forrás híján nem is lett folytatása (Hegedüs et al. 2016).

Összegezve, a Komplex telepprogram a kötelező partnerek kijelölésével és a telepfelszámolás intézményi kereteinek és tartalmi elemeinek meghatározásával - eltérően a modellprogram és a városrehabilitációs programok szemléletétől - a felülről vezérelt (top-down) és a mindent egy kaptafára (one-size-fits-all) fejlesztési szemlélethez áll közelebb (Pike, Rodríguez-Pose, Tomaney 2007).

Mindez szembemegy a helyi tudásra és adottságokra építő, a különböző kormányzási szintek és szereplők részvételén és dialógusán alapuló fejlesztési módszertannal, amely minden lehetséges szereplőt bevon a tervezés és a fejlesztés folyamatába, ezzel mozgósítva az endogén erőforrásokat.

A tervezési időszak utolsó szakaszában, 2014-ben a Dél-Dunántúl régióban modellkísérletként indult el egy participatív, a pályázati felhívást iteratívan kialakító, kifejezetten lakhatási integrációt célzó modellprogram. ${ }^{13} \mathrm{~A}$ modell lényege az volt, hogy pályázathoz előzetesen kiválasztott települések maguk is részt vettek a pályázati felhívás kialakításában. A pályázati felhívás kidolgozását, azaz 
a modellprogram kereteinek kialakítását mentorok segítették, akik a felhívás részleteit folyamatosan egyeztették a település vezetőivel és szereplőivel, a DDRFÜ és a ROP IH munkatársaival. Az egyeztetési folyamat célja az volt, hogy egy olyan felhívás szülessen, ami egyszerre fejezi ki a közpolitikát alakító állami szereplők és a helyi szereplők igényeit, fejlesztési céljait. A modellprogram végül a Dél-Dunántúl régió hat településén valósult meg, és kötelező eleme volt a szegregált területekről való kiköltöztetés. Ugyanakkor a projekt késlekedése miatt a megvalósításra nem jutott elegendő idő, a megvalósítás során a mentori követés is elmaradt, így helyi szinten a program nem feltétlenül sikeresen valósult meg (lásd az esettanulmányban). Hasonlóan a korábbi fejlesztési programokhoz, ebben az esetben is megfigyelhető az ágazati együttműködések helyett a források elosztására irányuló fragmentált kormányzásmód. Míg a TÁMOP alapvetően az EMMI-hez tartozott, ez a tervezési modellkísérlet a NGM-hez, ami a fejlesztéspolitikán belül egymással versengő és gyakran ellentétes szemléletü koncepciók párhuzamos jelenlétére utal.

\section{Telepfelszámolás változó intézményi környezetben}

Esettanulmányunkban ${ }^{14}$ bemutatjuk, hogy a Málta munkatársai által a pécsi György-telepen több mint egy évtizede végzett telepi szociális munka hogyan kapcsolódott a nemzeti szinten megfogalmazódó fejlesztésekhez (1. tábla), milyen erőforrásokat kellett helyben mozgósítani ahhoz, hogy országosan és nemzetközi szinten is jó gyakorlatként megjelenő programmá váljon. Az esettanulmány bemutatja, hogy nemzeti szinten megfogalmazódó fejlesztési elképzelések hogyan módosították, határozták meg a helyi fejlesztési törekvéseket, illetve a nemzeti szinten megfogalmazott fejlesztési elképzeléseket hogyan kellett a helyi realitáshoz igazítani, és ez miként jelent meg a mindennapi gyakorlatokban.

A György-telep kialakulása a 2. világháború utáni erőltetett iparosítást követő térbeli és társadalmi átrendeződés jellemző példája. A pécsi szénbányákat az államosításig az Első Duna Gőzhajózási Társaság üzemeltette, és építtetett a bányaalkalmazottak számára lakásokat a város keleti részén, a bányák elérhető közelségében. A városi lakótelepi lakások megépülésével a nehezen megközelíthető bányatelepekről egyre többen elköltöztek, a megüresedett lakásokba pedig a városi tanács - az országos telepfelszámolási programhoz kapcsolódóan - a Mecsek erdeiben felszámolt cigánytelepek lakóinak egy részét költöztette. Ugyanakkor a városnak arra nem volt forrása, hogy a bányatelepi lakásokat modernizálja, vagy legalább karbantartsa. Ennek eredményeképpen a nyolcvanas évekre a bányatelepek, köztük a György-telep, a város legrosszabb helyzetben levő lakónegyedeivé váltak. Egy idő után a stigmatizált telepekre a városi tanács, majd az önkormányzat már csak azokat a problémás családokat költöztette, akiket nem látott szívesen a belvárosban, így azok lassan a város „büntetőtelepévé” váltak (Zolnay 2009). 
A város fejlesztési dokumentumai szerint a Keleti Városrészben két, az ASZT által lehatárolt szegregátum található, a György-telep és a Hősök tere. A két szegregált terület egymás mellett helyezkedik el, a mindennapi térhasználatban nem különül el élesen egymástól. György-telepnek jellemzően a völgy aljában elhelyezkedő tucatnyi bányatelepi házat nevezik, ahol hozzávetőlegesen kétszázan élnek. György-telepet és a Hősök terét egy lépcső köti össze; a György-telepiek jellemzően ezen keresztül közelítik meg a Hősök terét és intézik mindennapi ügyeiket a városban, ugyanakkor a Hősök teréről az embereknek jellemzően nincs oka György-telepre lemenni, ahogy a pécsiek többsége sem járt soha ezekben a városrészekben: „Annyira elzárt helyen vannak, szerintem a pécsiek 80\%-a soha nem volt György-telepen" (helyi szakértő).

A völgy aljában megfelelő alapozás nélkül épített, kis alapterületü bányatelepi házak fizikai állapota, az infrastruktúra hiánya, a város és az ott elérhető szolgáltatások távolsága alapján az építészek és várostervezők egyértelmüen a telep felszámolását javasolták. Így a különböző fejlesztési dokumentumokban (IVSASZT) is György-telep felszámolása szerepelt. A város vezetése ugyanakkor folyamatosan halogatta a telep felszámolását. Ennek oka egyrészt az volt, hogy a kétezres években egy civil szervezet közremüködésével történt egy konfliktusos és eredményességét tekintve is kérdéses beavatkozás egy másik bányatelepen. Ahogy az egyik szakértő fogalmazott: "ott minden el lett követve, amit nem lett volna szabad". Másrészt a város vezetése politikai kockázatnak tekintette azt, hogy a stigmatizált városrészben élő családokat a város más körzeteibe költöztesse. A helyi civilek és várostervezők munkájának eredményeképpen a helyi önkormányzat ugyan érzékelte a problémát, de annak megoldására hiányzott az erős politikai elköteleződés és akarat.

Az elbeszélések szerint 2007-ben a Málta vezetője és helyi munkatársai az önkormányzat vezetőivel meglátogattak egy - éppen a közeli bányatelepen zajló kérdéses - fejlesztési programot. Az egyik önkormányzati képviselő javasolta, hogy látogassanak el a György-telepre is. A Málta egyik munkatársa így idézi fel a látogatást: "Amit ott láttunk, az valami ilyen, én nem tudom, bár nem egy úri világban éltem elötte, de ez valami más idődimenzió meg tér meg minden.” A látogatás után a Málta kezdeményezésére elindult a Jelenlét alapú szociális munka a telepen (Csonkáné Utasi, Dusa, Fehér 2011; Kiss 2011), amelynek költségeit - aminek számottevő része két szociális munkás bére volt - a Málta és a helyi önkormányzat közösen biztosította. A közösségi szociális munkát a Málta munkatársai projektkényszer nélkül, szakmailag függetlenül végezhették. Ez volt az az időszak, amikor a szociális munkásoknak volt tere és ideje beágyazódni, tudást szerezni a helyi közösség müködéséről, személyes kapcsolatokat építeni a telep lakóival. Ahogy az egyik szociális munkás megfogalmazta: „kristálytiszta szociális időszak volt”.

2010 után a telep felszámolásának terve részben a Málta közösségi szociális munkájának eredményeképpen, részben a megváltozott állami közpolitika hatására kezdett átalakulni. 
„2008 előtt a szándéka a jelenleg is regnáló polgármesternek az volt, hogy ezt a területet fel kell számolni. Gyakorlatilag a dózer módszerrel el kell tüntetni a föld színéről. Az nem volt kitalálva, hogy mi történik azokkal az emberekkel, akik ott vannak, de az igen, hogy az ilyenfajta területeket meg kell szüntetni. És akkor a Vecsei Miklós még 2008 előtt találkozott a polgármester úrral, beszélgettek erről nagyon sokat, és akkor meggyőzte arról, hogy de van néhány másik megoldás is, válasszunk egy másik utat, hátha Pécs ebből profitálhat"(helyi szakértő). Ez a másik út pedig a telepen végzett folyamatos közösségi és szociális munkával a telepi viszonyok konszolidációja volt. Mivel a György-telepi Jelenlét program a 2011-ben megjelenő TÁMOP felhívás egyik mintája volt, nem véletlen, hogy céljai tökéletesen illeszkedtek a Málta fejlesztési elképzeléseihez, és ez hosszú távon is kiszámítható finanszírozást nyújtott a már évek óta zajló szociális munka folytatásához. A TÁMOP projekt megvalósításán dolgozó konzorcium vezetője a városi önkormányzat volt, a programokat a városvezetés humán fejlesztésekért felelős egysége, a Természeti és Emberi Erőforrás Referatúra koordinálta. Azaz a TÁMOP projekt időszakában a városi önkormányzat elköteleződése találkozott a nemzeti szinten megfogalmazott fejlesztési elképzelésekkel. A kötelező partnerek mellett a programok egyik fontos konzorciumi partnere volt a helyi roma fejlesztési programokat megvalósító Khetanipe Egyesület is, aki a roma közösségi programokat koordinálta. A konzorciumon belül a feladatok és a felelősségek a kezdetektől pontosan lehatárolták, így György-telepen, folytatva az évekkel azelőtt megkezdett szociális munkát, szinte csak és kizárólag a Málta munkatársai dolgoztak, amivel helyismeretük, beágyazottságuk, kapcsolatuk a telepi családokkal csak tovább mélyült; erre támaszkodva, hosszú távú fejlesztési elképzeléseiknek megfelelően irányíthatták a folyamatokat a telepen.

A TÁMOP projekttel párhuzamosan a UNDP kezdeményezésére, a Málta és a Khetanipe megvalósításában egy másik kísérleti fejlesztés is indult Szabolcs-telepen, ami területileg magába foglalja György-telepet és annak tágabb környezetét, amit a helyiek összefoglalóan Hősök tere néven neveznek. A közösségi tervezésen és közösségépítésen alapuló projekt a helyi coachok segítségével közösen meghatározott kisléptékű fejlesztési célok alapvetően önkéntes, közösségi munkával történő megvalósításán alapult. A projekt során külön közösségi csoport alakult György-telepen és a Hősök terén. A két csoport munkája során elért sikerek és kudarcok nagyon különbözőek voltak. György-telepen, ahol évek óta folyt személyes szociális munka és segítés, ami az egyes egyének és a szociális munkások közötti együttmúködésen és bizalmon alapult, a közösségi célok megfogalmazása nehezen volt értelmezhető. Ezzel ellentétben a Hősök terén, ahol nem volt fejlesztési előzmény, a közösségi tervezés sikeres volt, amit számos közösségi akció és megvalósult kisebb fejlesztés is bizonyított. ${ }^{15}$

2014-ben a TÁMOP programot kiegészítő infrastrukturális fejlesztés a TIOP program és a Dél-Dunántúl régióban megvalósuló, alapvetően lakhatási integrációt célzó modellprogram (DDOP) szinte egyszerre indult a városrészben, de a progra- 
mok összeférhetetlensége miatt pontosan lehatárolt utcákban: a TIOP program György-telepen, a DDOP program a néhány utcányira levő Hősök terén. A TIOP program célja, a megfelelő lakhatási körülmények kialakítása, egy olyan közös célt tudott meghatározni és felmutatni a György-telepen lakó családok számára, amely képes volt mobilizálni a családokat és a programban - a szociális munkások több éves beágyazottságából és tudásából építkezve - egy közösségi tervezésen alapuló, az ott élő családok fejlesztési igényeit tükröző teleprehabilitációs tervet tudtak készíteni. Mivel György-telepen minden lakás önkormányzati tulajdonban volt, minden ott élő család lakását fel tudták újítani. A hosszú távú szociális és közösségi munka eredményeképpen a telep konszolidálódott, élhetővé vált, a fejlesztések az ott élő családoknak egyfajta perspektívát, legfóképpen azonban biztonságot nyújtottak, így a TIOP program keretében alig akadt olyan család, aki el szeretett volna költözni. Azaz a folyamatos közösségi munka, a személyes gondoskodás nem szándékolt következményeképpen a telepi lakosok elkezdtek ragaszkodni az immár biztonságot és kiszámíthatóságot nyújtó telepi léthez.

Ezzel szemben a DDOP projekt, ami a Hősök terei lakások felújítását, illetve az ott lakó családok integrált területre való költöztetését célozta, annak ellenére, hogy a tervezés során minden alulról jövő igényt és kezdeményezést igyekeztek becsatornázni a felhívásba, a Hősök terén konfliktusokat és feszültségeket generált. Megtörte ugyanis a korábbi közösségi tervezésen alapuló fejlesztések logikáját, és a forrás korlátossága miatt nem tudta kezelni a vegyes tulajdoni szerkezetből fakadó konfliktusokat. A UNDP projekt lépésről lépésre történő közösségi tervezési logikája teljesen ellentétes volt a DDOP projekt tervezési időszak szorításából fakadóan gyors és radikális változtatásaival. Ahogy az egyik szociális munkás összefoglalta: "[a közösen meghatározott] valamit valamiért elvét leöntöttük pénzzel, a felújitásért semmit se kellett tenni”. A Hősök terén élő családok szemszögéből a DDOP projekt szelektív és igazságtalan volt. Ezekben az utcákban önkormányzati és magántulajdonú házak egyaránt vannak, de a finanszírozási szabályok alapján a magántulajdonban levő házakat nem lehet EU-s fejlesztési forrásokból felújítani. Így volt olyan család, amelynek tagjai korábban nagyon aktívak voltak a közösségi és önkéntes munkában, ám mivel magántulajdonú házban éltek, nem voltak jogosultak a felújításra annak ellenére, hogy házuk rosszabb állapotban volt, mint egyes önkormányzati tulajdonú házaké. Hasonlóképpen, azok, akik a projekt által lehatárolt beavatkozási terület melletti utcákban éltek, akár önkormányzati tulajdonú házakban is, hiába voltak aktívak korábban a közösségi munkában, nem lettek jogosultak a felújításra. Ezek az ellentmondások aláásták a helyi közösség igazságosságról kialakított elképzeléseit. Ahogy egyik interjúalanyunk összefoglalta: "Mert, hogy ilyen a projekt jellege, és akkor ez, ez már egy kicsit más, mint a valamit valamiért elv, amit kitaláltak az emberek". Az önkormányzatnak és a Máltának nem volt sem forrása, sem kapacitása, s a megvalósítás szűkös időkeretei miatt ideje sem arra, hogy ezeket az egyenlőtlenségeket kezelje. ${ }^{16}$ 
Az 2014-es önkormányzati választások nemcsak az önkormányzat összetételében hoztak jelentős változásokat, de a fejlesztési projektek tervezésének és bonyolításának intézményi keretei is átalakultak, ami elsősorban a hátrányos helyzetü társadalmi csoportok fejlesztési programjaiért is elkötelezett Természeti és Emberi Erőforrás Referatúra megszüntetését, a helyi civilekkel való kooperáció visszaszorulását jelentette, ami pontosan illeszkedett a nemzeti szinten zajló centralizációs logikába. Mindezek a folyamatok megerősítették a Málta, mint nemzeti szinten is egyre hangsúlyosabb szerepet játszó fejlesztő szervezet pozícióját és lehetőségeit, a helyi fejlesztésekben erősödött a városháza és a Málta közötti együttműködés, ami elősegítette a helyi politika számára kényelmetlen szereplők kiszorulását a fejlesztésekből. Azt mondhatjuk, hogy a helyi önkormányzat kiszervezte a szegregált területek fejlesztését, az ahhoz kapcsolódó térbeli és társadalmi konfliktusok megoldását és azok politikai kockázatát a Máltának, mint egy a nemzeti szinten is egyre meghatározóbb fejlesztő szervezetnek.

A különböző projektek eltérő logikájából adódó feszültségeket, az egymásra torlódó projektek forrásbőségét, vagy éppen a projekt nélküli időszakok forráshiányát, a projektekből nem finanszírozható, de helyben megoldásra váró társadalmi problémák megoldását a Málta munkatársainak folyamatosan kezelniük kellett György-telepen és a Hősök terén. Ezt a munkát a Máltai Szeretetszolgálat, mint jelentős intézményi háttérrel és kapacitásokkal rendelkező országos szervezet biztos háttere nélkül nem tudták volna elvégezni. A helyi viszonyokhoz és igényekhez való rugalmas alkalmazkodás azonban kényszerủen informalizálta a rugalmatlan fejlesztési projektek megvalósításának egyes elemeit, így a helyiek és a város szemében a Málta tevékenysége egy idő után felvetette az átláthatóság kérdését (Tagai 2021). Ugyanakkor a Málta munkatársai voltak azok, akik biztos pontként mindig jelen voltak, akiken keresztül a helyiek a városi szociális és lakásosztállyal el tudták intézni ügyeiket, így egy ponton túl, a Málta lett a legfontosabb és egyben egyetemleges intézmény a helyiek szemében. Ahogy az egyik szociális munkás ezt megfogalmazta: „Miután tényleg mi vagyunk azok, akik a családok mellett folyamatosan ott vagyunk, velünk költöznek, és mi segitünk fölpakolni és lepakolni, és megyünk utána is folyamatosan, nyilván ez a fejekben leegyszerüsödik. És akkor máltás lakás."

A Málta munkatársainak hosszú távú elköteleződése és világos fejlesztési céljai az elmúlt tíz évben látványos eredményeket értek el György-telepen és a környező utcákban. Egyrészt a fizikai körülményekben a megújuló házak, a rendezett környezet, a közösségi terek kialakítása, másrészt az egyéni szociális munka és a közösségi tevékenységek eredményeképpen az egész városrész, az ott élő családok többségének helyzete konszolidálódott, és - a programok kötelező elemeként - jó néhány családot sikerült elköltöztetni a telepről.

Ugyanakkor fontos látni e változások korlátait és az ebből keletkező feszültségeket is: azok a családok, akik a Málta programjainak beavatkozási területén laknak és együttmüködnek a Málta munkatársaival, jelentős lakhatási és szociális 
támogatásban részesülnek, míg azok, akik a fejlesztés számára lehatárolt területen kívül élnek, továbbra is legfeljebb részlegesen vagy egyáltalán nem jutnak hozzá ezekhez a szolgáltatásokhoz. Egy másik perspektívából nézve, a pontszerü, egy-egy városrészre fókuszáló beavatkozások érintetlenül hagyták a társadalmi és térbeli egyenlőtlenségeket újratermelő intézményi struktúrákat. A városrészben élő gyerekek - néhány kivételtől eltekintve - továbbra is a közeli szegregált általános iskolába járnak, s bár a város szociális bérlakásrendszere áttekinthetőbb lett, a lakáskiutalások rendszere nem változott jelentős mértékben, a városvezetés nemhogy bérlakásépítési programot indított volna, de a város más pontjain folytatta az elhelyezés nélküli kilakoltatást. Azaz a helyi (és nemzeti) kormányzat közpolitikai rendszere nemcsak hogy nem illeszkedett, hanem éppen a fejlesztésekkel ellentétesen mozgott: a fejlesztési programokkal párhuzamosan a kirekesztés megerősödése, a szegényeket büntető társadalompolitika elötérbe kerülése, a középosztály támogatásának és pozíciójának megerősítése irányába mozdult el (Szikra 2014). Így a helyi Málta fejlesztési elképzelései és törekvései nem tudtak beágyazódni a helyi közpolitika rendszerébe, attól függetlenül, párhuzamosan működnek. „Málta csak kavics a tengerben, jó, amit csinálnak, viszont az egész lakásrendszer rossz" - ahogy egy helyi szakértő összefoglalta. Ezek a fejlesztési programok tehát a térbeli és társadalmi igazságtalanság problémáját csak egy szűk földrajzi területen belül tudják kezelni, de nem képesek arra, hogy továbbgyürüző hatásként (spillover effect) mindezt a közpolitikák és az ahhoz kapcsolódó intézményrendszer átalakításával az egész városra kiterjesszék.

\section{Következtetések}

Tanulmányunk a pécsi György-telep fejlesztésének elemzésén keresztül vizsgálta a helyi szint rendelkezésére álló lehetőségeket és kapacitásokat a telepfelszámolás megvalósításában, az állam által kialakított intézményi térben. A helyalapú fejlesztéspolitikai modell alapján áttekintettük, hogy a nemzeti intézményi és szabályozási környezet mennyiben találkozik a helyi adottságokkal és tudással, valamint a helyi igényekkel, és milyen erőforrásokat kell, illetve tud a helyi szint mozgósítani a lakhatási integráció megteremtése érdekében. Elemzésünk rámutatott arra, hogy a területi igazságosságot célzó helyalapú fejlesztések sikere nem csak helyi beavatkozásoktól függ, hanem döntően attól a nemzeti közpolitikai intézményrendszertől, amelybe a helyalapú fejlesztések is beágyazódnak. Ebben a fejlesztési szemléletben meghatározó szerep jut a külső intézményi környezetnek, amely a szubszidiaritás elvére, partnerségre és dialógusra épülő intézményrendszerén keresztül felülről segítheti az alulról induló fejlesztési kezdeményezéseket.

A helyi adottságokból kiinduló fejlesztések tartalma és megvalósíthatósága nagymértékben függ a hatalmat gyakorlók politikai szándékaitól. A kiindulópontot jelentő, 2005-ben indult SZMM-es modellprogram elsődleges fejlesztéspoliti- 
kai célja, a lakhatási integráció megvalósítása egyrészt a lokális szint szelektív elköteleződése miatt, másrészt azért hiúsult meg, mert (jellemzően) a helyi fejlesztési elképzelések és célok sem kristályosodtak ki, így az egyes projektek vagy el sem indultak, vagy éppen ellentétes irányú folyamatokat, konfliktusokat generáltak a településeken. A pécsi eset sikere abból is adódik, hogy a helyi Málta és az országos szint fejlesztési törekvései egybecsengtek, sőt a Málta programja országos szinten mintaadóvá vált, ugyanakkor a városvezetéstől helyi szinten nem igényelték az erőteljes politikai elköteleződést, a helyi konfliktusok felvállalását.

Pécsett a 2014-es önkormányzati választásokat követően a helyi intézményi változások leképezték az országban 2010 után végbemenő intézményi trendeket: centralizáció és a központi állam növekvő szerepe a helyi fejlesztések meghatározásában, hierarchikus közpolitikai döntések, hegemón intézményi gyakorlatok és az állam szelektív kivonulása a szegénységet és kirekesztést kezelő közpolitikai területekről. A helyi intézményrendszerben ezek a trendek az önkormányzati kapacitások leépülésében és átalakulásában, ezzel párhuzamosan a Málta kapacitásainak megerősödésében és abban érhetők tetten, hogy a városi marginalitást mérséklő fejlesztésekben meghatározó pozícióba került, amit nemzeti szinten az egyházi szervezetek növekvő közpolitikai szerepvállalása is támogatott. A helyi önkormányzat szükülő mozgástere a helyi közpolitikák kialakításában és az intézmények müködtetésében az informális megoldások egyre növekvő jelentőségét eredményezte.

Összességében, a RELOCAL projekt más esettanulmányaival összhangban (Keller, Virág 2021, lásd még Tagai 2021), a pécsi György-telep története is arra hívja fel a figyelmet, hogy az állam területi igazságosság iránti elköteleződése kulcsfontosságú a helyalapú fejlesztések hatékonysága szempontjából. A központi állam elköteleződése stabilitást hozhat a helyi és központi állami szint közötti viszonyok kormányzásába, és lehetővé teheti azokat a strukturális változásokat, amelyekbe ágyazódva a helyalapú fejlesztések pontszerü beavatkozásai hosszú távon kiszélesíthetők. Ez az állami elköteleződés azt is jelenti, hogy az állam a közpolitikai döntések előkészítésében és megvalósításában a közjavak minél szélesebb társadalmi rétegeknek felkínált elérését, a közszereplők által konszenzusos alapon meghatározott közjót tekinti mérvadónak. Esettanulmányunk arra világított rá, hogy a központi állam elköteleződése nélkül a fejlesztések pontszerű beavatkozásai nem tudnak beágyazódni a közpolitika intézményrendszerébe. Ugyanakkor a fejlesztések hatékonyságának vagy éppen elmaradásának akadálya lehet a helyi szint elköteleződésének a hiánya is. A pécsi programok elemzése rámutatott, hogy azok gyakran a helyi szint visszajelzései, a megvalósítás konfliktusai alapján puhultak fel és módosultak. A programok elemzése és a pécsi György-telep esettanulmánya az EU többszintű kormányzási modelljében megvalósított, helyi adottságokból kiinduló fejlesztési stratégiájának gyengeségeire is rávilágít. A többszintü kormányzásmód intézményi keretéből adódóan, a nemzeti szint politikai és intézményi konstellációi tartósan befolyásolhatják a helyi fejlesztéseket, 
akár az EU-s fejlesztési eszközök célrendszerével ellentétben is. A területi igazságosság elvei iránti állami elkötelezettség hiányában, a helyi fejlesztési beavatkozások a nemzeti kormányok politikai céljainak megfelelően módosulhatnak, akár a társadalmi kohézió céljának ellenében is.

\section{Jegyzetek}

1 A pécsi György-telepen történt fejlesztéseket elemző esettanulmány (Jelinek,Virág 2019) terepmunkáját 2017-2018-ban végeztük, amikor a 2007-2014 (2016) időszak fejlesztései éppen lezárultak. Ezért tanulmányunk is erre az időszakra vonatkozik.

2 1021/2004 (III.18) Kormányhatározat

3 A roma politika intézményrendszerének változásáról lásd bővebben Kállai 2006.

42005 és 2009 között összesen 4mrd forint forrás állt rendelkezésre (Petrovácz, Somogyi, Teller 2010).

5 Míg a modellprogramok, majd a későbbiekben az arra épülő TÁMOP programok a városi és kistelepülési (falusi) telepeket azonosan kezelte, a ROP programra csak városok pályázhattak. Így a városok a 2007-2014-es időszakban több forrásból is pályázhattak telepfelszámolásra (lásd az esettanulmányt). Ezt a következő fejlesztési időszakban oldották fel, amikor külön OP-ból lehetett pályázni falusi és városi telepek rehabilitációjára.

6 Városrehabilitáció 2007-2013-ban, Kézikönyv a városok számára, ami szakpolitikai ajánlásként jelent meg 2007-ben, majd a javított kiadás Városfejlesztési Kézikönyvként 2009-ben.

7 TÁMOP-5.3.6-11/1 Komplex telep-program (komplex humán szolgáltatás hozzáférés biztosítása)

8 Esettanulmányunk helyszínén, György-telepen az NFÜ felszámolása és a fejlesztéspolitikai mező közvetlen átalakulása "kettévágta” a helyi szinten megvalósított telepfelszámolási és fejlesztési programokat. A TIOP György-telep és a DDOP Hősök tere programok helyi tervezése és megvalósítása már e politikailag kontrollált, centralizált intézményi logika mentén zajlott.

9 A TKKI-t 2016-ban felszámolták, a feladat előbb az Szociális és Gyermekvédelmi Főigazgatósághoz, majd a Társadalmi Esélyteremtési Főigazgatósághoz került.

10 A beavatkozás első fázisaként a folyamatos szociális munkás jelenlét biztosításával a kölcsönös bizalomépítés, napi kapcsolatteremtés zajlik a szegregátumokban élőkkel, illetve a helyi szereplők bevonására, aktivizálására kerül sor. (...) A helyi szükségleteknek megfelelő, minimum két fő szociális munkás elhelyezésére és egyéni szolgáltatások nyújtására alkalmas „Csillag Szolgáltatópont” kialakítása a szegregátum területén, illetve közvetlen közelében (Pályázati felhívás 14-15.).

11 A felzárkóztatás fogalma a hatvanas években a cigányosztályok kialakításához kapcsolódott (Kemény 2001), majd a kilencvenes években a felzárkóztató normatíva bevezetésével került újra a társadalompolitika fogalomtárába, amit az uniós csatlakozási folyamat részeként, nemzetközi szervezetek ajánlására az esélyegyenlőségelvű fejlesztéspolitika váltott fel.

12 Lakhatási beruházások támogatása (TIOP 3.2.3/A-13)

13 Lakhatási integrációt modellező szociális célú település-rehabilitációs kísérleti projektek megvalósítása (DDOP 4.1.2.B-13)

14 A tanulmány e fejezete a RELOCAL kutatás keretében készült és publikált esettanulmány empirikus tapasztalataira és elemzésére épül (Jelinek, Virág 2019).

15 Egyik legnagyobb sikerként említették, hogy sikerült áthelyeztetniük egy buszmegállót, ami a gyerekek iskolába járását biztonságosabbá tette. A közösségi munka egyik kiemelkedő eseménye pedig a Hősök terén elhelyezett időkapszula kivitelezése volt.

16 Pécsett három telepen történt ebből a programból beavatkozás. Ott, ahol a telep teljes egészét megszüntették és minden lakót elköltöztettek, nem volt hasonló feszültség. 


\section{Köszönetnyilvánítás}

A tanulmány a RELOCAL (Resituating the Local in Cohesion and Territorial Development) H2020 kutatás keretében készült (No. of Grant Agreement 727097).

This work was supported by the European Union's Horizon 2020 research and innovation programme under grant agreement No. 727097, project RELOCAL (Resituating the local in cohesion and territorial development), $2016-2021$

\section{Irodalom}

Bachtler, J., Mendez, C., Oraže, H. (2013): From Conditionality to Europeanization in Central and Eastern Europe: Administrative Performance and Capacity in Cohesion Policy. European Planning Studies, 4., 1-23. https://doi.org/10.1080/09654313.2013.772744

Barca, F., McCann, P., Rodríguez-Pose, A. (2012): The Case for Regional Development Intervention: Place-based versus Place-neutral Approaches. Journal of Regional Science, 1., 134-152. https:// doi.org/10.1111/j.1467-9787.2011.00756.x

Beer, A., McKenzie, F., Blazek, J., Sotarauta, M., Ayres, S. (2020): Requirements and Challenges of Place-Based Policy. Regional Studies Policy Impact Books, 2: 1., 39-55. https://doi.org/ 10.1080/2578711X.2020.1783899

Berey K. (1990): A szociális követelményeknek meg nem felelő telepek felszámolása. In: Berey K., Horváth Á.(szerk.): Esély nélkül. Vita Kiadó, Budapest, 5-72.

Bruszt, L. (2002): Market Making as State Making - Constitutions and economic development in Postcommunist Eastern Europe. Constitutional Political Economy, 13., 53-72. https://doi.org/10.1023/ A:1013687107792

Csonkáné Utasi K., Dusa Á., Fehér A. (2011): A város peremén: Györgytelep. Civil Szemle, 3., 97-113.

Dabrowski, M. (2014): Towards place-based regional and local development strategies in Central and Eastern Europe? EU cohesion policy and strategic planning capacity at the subnational level. Local Economy, 4-5., 378-393. https://doi.org/10.1177/0269094214535715

Domokos V., Herczeg B. (2010): Terra Incognita: magyarországi szegény- és cigánytelepek felmérése - első eredmények. Szociológiai Szemle, 3., 82-99.

Durst J. (2010): „Minden évben máshogy fordul a világ” A telepfelszámolástól a szegregált cigány faluig. An Blok, 4., 34-38.

Farkas Zs. (2018): Búcsú a cigányteleptől? Esély, 1., 42-66.

Gilbert, N. (1989): The Enabling State: Modern Welfare Capitalism in America. Oxford University Press, Oxford

Hegedüs J., Kullmann Á., Somogyi E., Teller N. (2016): Komplex telep-program értékelése (TÁMOP 5.3.6-11) Városkutatás Kft., Budapest (Kézirat)

Hegedüs J., Péteri G. (2015): Közszolgáltatási reformok és a helyi önkormányzatiság. Szociológiai Szemle, 2., 90-119.

Horlings, L., Roep, D., Wellbrock, W. (2018): The role of leadership in place-based development and building institutional arrangements. Local Economy, 3., 245-268. https://doi.org/10.1177/ 0269094218763050

Janky B., Kemény I. (2004): Települési és lakásviszonyok. Beszélő, 4., 96-110.

Jelinek, Cs., Virág, T. (2019): György-telep. Ten Years of Urban Regeneration in a Poor Neighbourhood, Hungary. RELOCAL Case Study No 14/33. Joensuu: University of Eastern Finland

Jelinek Cs. (2019): A városrehabilitáció korszakai Magyarországon: Az állam szerepe marginális városi terek (újra)termelésében. Tér és Társadalom, 4., 17-37. https://doi.org/ 10.17649/TET.33.4.3180.

Jelinek Cs. (2020): „Gúzsba kötve táncolunk” - Zsugorodás és a kontroll leszivárgásának a politikai gazdaságtana magyarországi középvárosokban. Szociológiai Szemle, 4., 115-136.

Kállai E. (2006): Kormányzati romapolitika az elmúlt négy évben. In: Kállai E., Törzsök E. (szerk.): Átszervezések kora. Cigánynak lenni Magyarországon. Jelentés 2002-2006. Európai Összehasonlító Kisebbségkutatások Közalapítvány, Budapest, 187-203. 
Katona N., Somogyi E., Teller N., Tönkő A., Hegedüs J. (2020): Megérkezés és elköteleződés. Négy hazai és négy romániai testvértelep élete a Jelenlét programban. Városkutatás Kft., Budapest (Kézirat)

Kegye A. (2015): Áldott szegregáció. Fundamentum, 1., 75-85.

Keller J. (2020): Csepp a tengerben - Gyerekesély program az Encsi kistérségben/járásban avagy a helyi adottságokra építő fejlesztések lehetőségei. Tér és Társadalom, 4., 45-70. https://doi.org/ 10.17649/TET.34.4.3309.

Keller, J., Virág, T. (2021): “A Drop in the Sea or Catalyst for Change: Diverse Effects of the PlaceBased Approach in Europe. "European Planning Studies doi:10.1080/09654313.2021.1928047

Kemény I. (2001): A romák és az iskola. Beszélo", 1, http://beszelo.c3.hu/cikkek/a-romak-es-az-iskola (Letöltés: 2010. 06. 15.)

Kiss D. (2011): Cigánytelep nyolctól négyig. Dávid naplója. Magyar Máltai Szeretetszolgálat

Kovai C., Szőke A. (2021): A „siker kovácsai”: a Biztos Kezdet gyerekházak és a tanodák intézményesülésének dilemmái. Tér és Társadalom, 4., 166-189. https://doi.org/10.17649/TET.35.4.3380

Kozákné Keszei V. (2001): Cigánypolitika Magyarországon. Elmélet és gyakorlat az 1960-as évek elejétól a 90-es évekig. Romológiai Kutatóintézet Közleményei 5. Romológiai Kutatóintézet, Szekszárd, 96-135.

Ladányi J. (2012): Leselejtezettek. L'Harmattan, Budapest

Ladányi J., Szelényi I. (2004): A kirekesztettség változó formái. Napvilág Kiadó, Budapest

Lengyel G. (2006): Cigánytelepek egykor és ma. In: Kállai E., Törzsök E. (szerk.): Átszervezések kora. Cigánynak lenni Magyarországon Jelentés 2002-2006. Európai Összehasonlító Kisebbségkutatások Közalapítvány, Budapest, 56-91.

McAleavey, P. (1995): Policy implementation as incomplete contracting: the European regional development fund. European University Institute, EUI PhD theses, Department of Political and Social Sciences Retrieved from Cadmus, European University Institute Research Repository, Florence http:// hdl.handle.net/1814/5274

Madanipour, A., Shucksmith, M., Talbot, H. (2017): RELOCAL: Resituating the Local in Cohesion and Territorial Development: Conceptual Framework for the Project. https://relocal.eu/wp-content/uploads/

Mezei C. (2019:) Fejlesztési kényszerpályák. Dialóg Campus Kiadó, Budapest

Mike Gy. (2013): Társadalmi felzárkózás = szegregáció? Jogelméleti Szemle, 2., 103-115.

Misetics B. (2013): Javaslatok egy egalitariánus lakáspolitikai reform fő irányaira: politikai és szakpolitikai vázlat. Esély, 1., 39-73.

Pálné Kovács I. (2014): Az önkormányzati rendszer és a területi közigazgatás átalakulása 2010-2013. MTA Law Working Papers. 02. Magyar Tudományos Akadémia, Budapest

Petrovácz R., Somogyi E., Teller N. (2010): Telepeken és telepszerü lakókörnyezetben élök integrációs programjának értékelése. Városkutatás Kft., Budapest (Kézirat)

Pierre, J. (2014): Can Urban Regimes Travel in Time and Space? Urban Regime Theory, Urban Governance Theory, and Comparative Urban Politics. Urban Affairs Review, 6., 864-889. https:// doi.org/10.1177/1078087413518175

Pike, A., Rodríguez-Pose A., Tomaney, J. (2007): What kind of Local and Regional Development and for Whom? Regional Studies, 9., 1253-1269. https://doi.org/10.1080/00343400701543355

Révész S., Zolnay J. (2009): Ami történt, az a gettó csinosítgatása. Havas Gáborral Révész Sándor és Zolnay János beszélgetett. Beszélő 4. https://beszelo.c3.hu/cikkek/"ami-tortent-az-a-gettocsinositasa" (Letöltés: 2012.03.09.)

Soja, E. (2009): The city and spatial justice. Justice Spatiale/ Spatial Justice 01. http://www.jssj.org. (Letöltés: 2019.04.02.)

Somlyódyné Pfeil E. (2020): A vidéki térségek felzárkóztatásának feltételei és eszközei uniós szemszögből - Visszatérés az endogén erőforrásokra alapozott fejlesztési szemlélettől az újraelosztó támogatáspolitikához Magyarországon. Tér és Társadalom, 4., 18-44. https://doi.org/ 10.17649/TET.34.4.3298

Somogyi E. (2013): A területfejlesztési esélyegyenlőség-elvü támogatáspolitika vizsgálata. Városkutatás Kft., Budapest (Kézirat)

Stoker, G. (1998): Governance as Theory: Five Propositions. International Social Science Journal, 50., 17-28. https://doi.org/10.1111/1468-2451.00106 
Surubaru, N.-C. (2016): Administrative capacity or quality of political governance? EU Cohesion Policy in the new Europe, 2007-13. Regional Studies, 6., 844-856. https://doi.org/10.1080/00343404.2016.1246798

Szikra, D. (2014): Democracy and welfare in hard times: The social policy of the Orban Government in Hungary between 2010 and 2014. Journal of European Social Policy, 5., 486-500. https://doi.org/ $10.1177 / 0958928714545446$

Tagai, G. (2021): Igazságos szolgáltatások? A közérdekủ szolgáltatások hatása a társadalmi, térbeli viszonyokra. Tér és Társadalom, 4., 33-59. https://doi.org/10.17649/TET.35.4.3369

Telle, S., Špaček, M., Crăciun, D. (2019): Divergent Paths to Cohesion: The (Unintended) Consequences of a Place-Based Cohesion Policy. In: Lang, T., Görmar, F. (eds.): Regional and Local Development in Times of Polarisation. Palgrave Macmillan, Singapore, 149-72. https://doi.org/10.1007/978-981-131190-1.

Teller N. (2011): Adaptációs csapdák. Hipotézisek a romák lakásmobilitásáról a 2010-es roma adatfelvétel lakásváltoztatási kérdéseire adott válaszok és a korábbi cigányfelvételek lakásmobilitási adatai alapján. In: Kurucz E. (szerk.): Roma kutatások, 2010 - élethelyzetek a társadalom peremén. Nemzeti Család- és Szociálpolitikai Intézet, Budapest, 203-218.

Váradi M., Virág T. (2015): A térbeli kirekesztés változó mintái vidéki terekben. Szociológiai Szemle, 1., $89-113$.

Varró Sz. (2008): Az MSZP-SZDSZ-kormányok romapolitikája 2002 óta. Magyar Narancs 05.29

Virág T. (2006): A gettósodó térség. Szociológiai Szemle, 1., 60-76.

Virág T. (2008): Programok a cigánytelepek felszámolására. In: Törzsök E., Paskó I., Zolnay J. (szerk.): Jelentés 2007. A gyülölet célkeresztjében. Európai Összehasonlító Kisebbségkutatások Közalapítvány, Budapest, 165-178.

Virág T. (2020): Demográfiai polarizáció, térbeli és társadalmi marginalizáció két zsugorodó középvárosban. Szociológiai Szemle, 4., 27-49.

Wozniakowski, P. T., Schimmelfennig, F., Matlak, M. (2018): Europeanization Revisited: An Introduction. In: Matlak, M., Schimmelfennig, F., Wozniakowski, P. T. (eds.): Europeanization Revisited: Central and Eastern Europe in the European Union. European University Institute, Robert Schuman Centre for Advanced Studies, Florence https://doi.org/10.2870/675963

Zolnay J. (2009): Oktatáspolitika és városfejlesztés Pécsett. Beszélő, 2, http://beszelo.c3.hu/cikkek/ terszemle (Letöltés: 2015.04. 20.) 


\section{Melléklet}

1.táblázat: Nemzeti és helyi szinten megvalósuló programok 2005-2016 Settlement programs at the national and local levels 2005-2016

\begin{tabular}{|c|c|}
\hline Nemzeti szinten megfogalmazott programok & $\begin{array}{c}\text { Helyi szinten (György-telepen és Hösök terén) } \\
\text { megvalósított programok }\end{array}$ \\
\hline \multicolumn{2}{|l|}{ 2005-2009 } \\
\hline $\begin{array}{l}\text { Roma telepeken élők lakhatási és szociális } \\
\text { integrációs modellprogram - OFA-SZMM hazai } \\
\text { forrás }\end{array}$ & $\begin{array}{l}\text { Jelenlét program/szociális munka } \\
\text { György-telepen 2007-től folyamatosan, MMSZ } \\
\text { és a városi önkormányzat finanszírozása }\end{array}$ \\
\hline \multicolumn{2}{|l|}{$2007-$} \\
\hline \multicolumn{2}{|l|}{$(\mathrm{ROP})$} \\
\hline 2012 & $2012-2014$ \\
\hline \multirow[t]{2}{*}{$\begin{array}{l}\text { TÁMOP 5.3.6-11/1 (ESZA) Komplex telepprog- } \\
\text { ram - jelenléten alapuló szociális munka, } \\
\text { szolgáltatások biztosítása a telepen }\end{array}$} & $\begin{array}{l}\text { György-telep - TÁMOP Komplex telep- } \\
\text { program (ca.500 000 EUR) }\end{array}$ \\
\hline & $\begin{array}{l}\text { UNDP modellprogram - közösségfejlesztés (ca. } \\
80000 \text { EUR) }\end{array}$ \\
\hline $2014-2016$ & $2014-2016$ \\
\hline $\begin{array}{l}\text { TIOP (EFRD) 3.2.3.A-13/1 TÁMOP 5.3.6 - 116/1 } \\
\text { kiegészítő felhívás, lakások felújítása, integrált } \\
\text { lakókörnyezetbe költöztetés }\end{array}$ & $\begin{array}{l}\text { TIOP György-telep (ca. } 1100000 \text { EUR): } 22 \text { ház } \\
\text { felújítása, } 5 \text { lakás vásárlása integrált környe- } \\
\text { zetben (TIOP) }\end{array}$ \\
\hline $\begin{array}{l}\text { DDOP 4.1.2/B-13 (EFRD) } 6 \text { támogatott program } \\
\text { a Dél-Dunántúl régióban lakások felújítása, } \\
\text { integrált lakókörnyezetbe költöztetés és } \\
\text { szociális munka }\end{array}$ & $\begin{array}{l}\text { DDOP Hősök tere (ca. } 1200000 \text { EUR): } 20 \text { ház } \\
\text { felújítása, } 10 \text { lakás vásárlása integrált könye- } \\
\text { zetben és szociális munka }\end{array}$ \\
\hline
\end{tabular}

Forrás: saját szerkesztés 